\title{
Systematic destruction of K-feldspar in deeply buried rift and passive margin sandstones
}

\author{
M. WILKINSON ${ }^{1}$, KITTY L. MILLIKEN ${ }^{2} \&$ R. STUART HASZELDINE ${ }^{1}$ \\ ${ }^{1}$ Department of Geology and Geophysics, Grant Institute, Kings Buildings, University of Edinburgh, Edinburgh, \\ ScotlandEH93JW, UK (e-mail: m.wilkinson@glg.ed.ac.uk) \\ ${ }^{2}$ Department of Geological Sciences, University of Texas at Austin, Austin, Texas 78713, USA
}

\begin{abstract}
Systematic patterns of detrital K-feldspar decline with increasing burial depth are revealed during deep burial $(1.5-4.5 \mathrm{~km})$ of sandstones in diverse sedimentary basins from three rift and two passive margin settings in the North Sea and USA Gulf Coast. K-feldspar destruction is predominantly by dissolution, though in-situ alteration to albite also occurs. Dissolution can remove up to $15 \%$ solid volume of the rock by $4.5 \mathrm{~km}$, so that primary arkosic sandstones become diagenetic quartzarenites at depth, with increased secondary:primary porosity ratios. The quantity of K-feldspar destroyed during temperature increase is very variable: $0.05-1.0 \%$ solid volume $/{ }^{\circ} \mathrm{C}$. Compaction continues during deep burial and petrographic textures diagnostic of secondary porosity are destroyed (so that many sandstones preserve $<10 \%$ secondary porosity). Alternative explanations for $\mathrm{K}$-feldspar reduction with depth, including changes in original sediment provenance controlling the observed variation of feldspar with depth, or that source areas changed during deposition, can be refuted. Deeply buried sandstones are not reliable records of depositional composition.

Exceptions to this scenario of detrital K-feldspar dissolution are noted. Proximity of K-rich evaporites, high $\mathrm{SiO}_{2}$ and $\mathrm{K}^{+}$activity due to the breakdown of volcanic clasts or very low $P_{\mathrm{CO}_{2}}$ can stabilize both $\mathrm{K}$-feldspar and a suite of K-rich cements.
\end{abstract}

Keywords: feldspar, sandstone, diagenesis, secondary porosity, compaction.

Exploration for hydrocarbon reserves requires prediction of the porosity and permeability of deeply buried sandstones. This pore space may be primary, as gaps between detrital sediment particles; or may be secondary, formed by dissolution of unstable detrital particles or cements. Feldspar is the most abundant unstable detrital mineral within rift and passive margin basins (Dickinson \& Suczek 1979), the fate of which during burial is hotly debated, and has both academic and economic implications. If feldspar remains unaltered then deeply buried, or exhumed, sandstones are reliable records of the original sediment composition, and no extra secondary porosity has been created. However, if feldspar dissolves during burial and the products are exported from the host sandstone, then the deeply buried sandstone may change its bulk composition, and economically important secondary pore space may be created, partially replacing the primary porosity lost by physical compaction.

In petroleum basins, secondary porosity resulting mainly from carbonate dissolution was recognized by Schmidt \& McDonald (1977), though doubted by many others. The contribution of feldspar dissolution to secondary porosity was considered minor by Schmidt \& McDonald (1977), though more recent work has shown that feldspar dissolution can be volumetrically dominant (e.g. Harris 1992). In some cases the secondary pore space created by feldspar dissolution may be infilled by clay reaction products (Giles \& de Boer 1990), or the secondary pore space may be a net contribution to total rock porosity (McLaughlin et al. 1994). While it can be presumed that feldspar will dissolve in contact with undersaturated pore fluid, the timing of feldspar dissolution during burial is contentious. Bjørlykke (1984) proposed that the formation of secondary porosity only occurs at shallow depths $(<1.5 \mathrm{~km})$, where meteoric porewaters can remove reaction products with large water fluxes, a concept which is still current with some workers (Bjørlykke 1998). In contrast Milliken (1988, 1992), Milliken et al. (1989), Harris (1992), Wilkinson \& Haszeldine (1996) and others inferred K-feldspar dissolution during deep burial $(>3.0 \mathrm{~km})$ by demonstrating systematic decreases of feldspar at greater depths within individual sandstones and surrounding shales. The total amount of feldspar which has undergone dissolution may be impossible to estimate by petrographic methods, due to the destruction of diagnostic textures during sediment compaction (Wilkinson et al. 1997). Critics have suggested that evidence for feldspar decrease with depth is, at best, equivocal, and may be due to primary variations in sandstone composition and not due to diagenetic dissolution (Bjørlykke 1998; Oxtoby \& Gluyas 1997). This would necessitate shallow-buried sandstones near a basin edge being depositionally enriched in feldspar, relative to deeper buried sandstones deposited more distally closer to the basin centre, or require that the nature of the sediment source area changed during the deposition of the sandstone. These depositional alternatives were considered to be statistically improbable in the data from the Fulmar Formation (Wilkinson \& Haszeldine 1997). Another way of investigating if K-feldspar dissolution occurs during deep burial is to compile suites of data relating to sandstone composition from different basins. If a common pattern of feldspar decline during deep burial is discovered in several basins, then a hypothesis linking dissolution process to burial can be supported, and the alternative coincidence of burial depth and depositional variation can be discounted.

It is the purpose of this paper to present empirical evidence that K-feldspar dissolution during deep burial $(1.5-4.5 \mathrm{~km})$ 


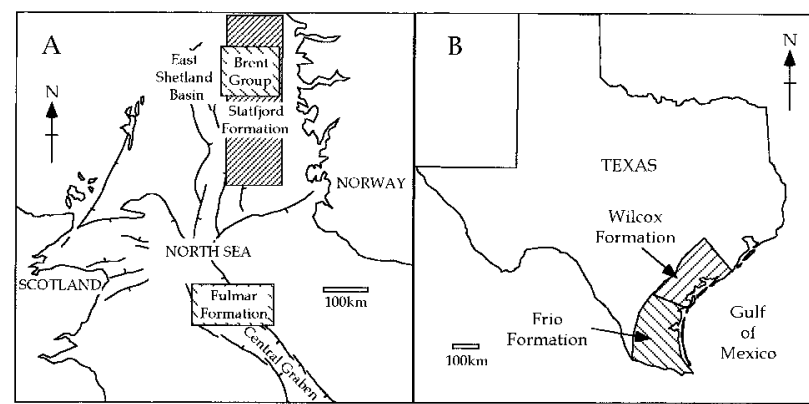

Fig. 1. Location map of study areas in the North Sea (a) and Texas, USA (b).

does occur within sandstones from rift and passive margin settings. Data has been compiled from sandstones deposited within a variety of different palaeoenvironments, of different geological ages, in basins of different origins within an overall rift/passive margin setting. The following selection criteria were used.

(1) Data set must be published or otherwise available to us. We do not have access to confidential company data-bases.

(2) Basin must be at maximum burial depth at present day, or else maximum burial depths would have to be inferred. In the case of the Jurassic North Sea basins (which underwent inversion in Early Cretaceous prior to deep burial) we assume that the post-inversion burial significantly exceeds that which took place pre-inversion. In practice this criterion limits data to that collected from sub-surface cores.

(3) Data set must be large, such that averaging of data with depth reduces errors sufficiently for depth trends to be apparent. We acknowledge that there is much variability in initial feldspar contents of sands, even within a single facies/grain size/sorting category, but we maintain that changes in bulk composition with depth can be observed using averaged data.

(4) Data set must cover the depth range of interest (approximately $3000-4500 \mathrm{~m}$ ) with minimal change in facies/grain size/sorting.

(5) Data set should be from an area with a uniform initial provenance, hence minimizing problems with the depositional variability of the sands. This is the most subjective of the selection criteria, and usually impossible to prove conclusively.

All the data sets which fit these criteria are from oil provinces, due to economic constraints (Fig. 1): Texas Gulf Coast (Frio Formation, Wilcox Formation, Plio-Pleistocene and modern); UK Central Graben (Fulmar Formation); the East Shetland Basin of Norway (Etive Formation of the Brent Group and the Statfjord Formation). The sediments range from Lower Jurassic to modern in age, and were deposited in environments spanning fluvial, deltaic, tidal channel and shallow marine shelf. While feldspar decline with depth is observed in all these sandstones from differing tectonic and geographical settings, there are other basins where such a decline is not supported by available data (e.g. Stevens Sandstone, San Joaquin Basin, California (Boles 1987) and Murihiku Supergroup, New Zealand (Boles \& Coombs 1977)). The implications of these exceptions, which are from volcanic arc and strike-slip basins, are discussed below.

\section{Methods}

Point count data is from 200-300 points per thin section, with thin sections stained for alkali feldspar (and assorted other minerals depending upon the origin of the thin-sections). Numbers of thin-sections counted vary from 377 (Frio Formation) to 75 (Mississippi Delta sands) (see Fig. 2). Mineral percentages are reported relative to solid volume as $100 \%$. The Frio Formation (Texas Gulf Coast) data was produced by the University of Texas, Austin. One set was collated by L.S. Land and E.F. McBride, and was reported in Milliken et al. (1989), the other set was produced as part of a regional study by the Bureau of Economic Geology at the University of Texas at Austin and was reported in Loucks et al. (1984). The latter data set also included data from the Wilcox Formation, which was supplemented by data from Fisher (1982). Because the Texas Gulf Coast sedimentary rocks contain an abundance of chemically unstable grains (rock fragments, plagioclase feldspars and carbonate clasts) and these change in abundance with depth, it is necessary to present feldspar compositional data as a ratio with quartz, on the assumption that the quantity of detrital quartz remains constant during burial. Petrographic examination shows only minimal evidence for pressure dissolution of detrital quartz during burial. For the Texas Gulf Coast data, the K-feldspar abundance is hence presented using the following ratio:

$$
100 \times \text { alkali feldspar/(alkali feldspar }+ \text { detrital quartz). }
$$

The sedimentary rocks from the North Sea contain only small quantities of chemically unstable grains (except for alkali feldspars!) making this correction unnecessary.

There are significant variations in sediment provenance along the Texas Gulf Coast, with the southern part being richer in volcanic debris derived from the Rio Grande than the northern arkosic sediments derived from the Mississippi (Loucks et al. 1984). We have therefore plotted data from restricted geographical areas for the Frio and Wilcox formations (Fig. 1b). The petrographic data from the PlioPleistocene sandstones of the Mississippi Gulf Coast are from Milliken (1985). The composition of present day sand within the Mississippi River is from Russell (1937).

The petrographic data for the Etive Formation (Brent Group) is from Bjørlykke et al. (1992) and Glasmann et al. (1989). Note that the former data set is derived by XRD and not by point-counting. Given the relatively large numbers of samples involved in the study and the fact that K-feldspar is a major constituent of these sands, then XRD analysis should be adequate to document changes in bulk composition. We have chosen the Etive Formation as it represents a barrier shoreface which should have had an initially uniform mineralogical composition due to wave-reworking. The Fulmar Formation data are from Wilkinson \& Haszeldine (1996), and are from the Fulmar and Clyde fields only. The Fulmar Formation is a shallow marine shelf deposit (Howell et al. 1996) upon which tidal and wave processes should have produced a uniform average mineralogy. Inevitably, we are averaging the compositions of sands of different facies. However, within the chosen formations, facies variations are limited due to the restricted range of sedimentary environments represented. Note that the Statfjord data are subdivided into two distinct facies (fluvial channel and marine bar) but that they show identical compositional trends (Ramm \& Ryseth 1996, fig. 9). It is only by using relatively large data sets that regional trends in average composition can be discerned, unobscured by local fluctuations.

The authors recognize that neither the point-counting of thin-sections, nor XRD of powders, are ideal methods of 

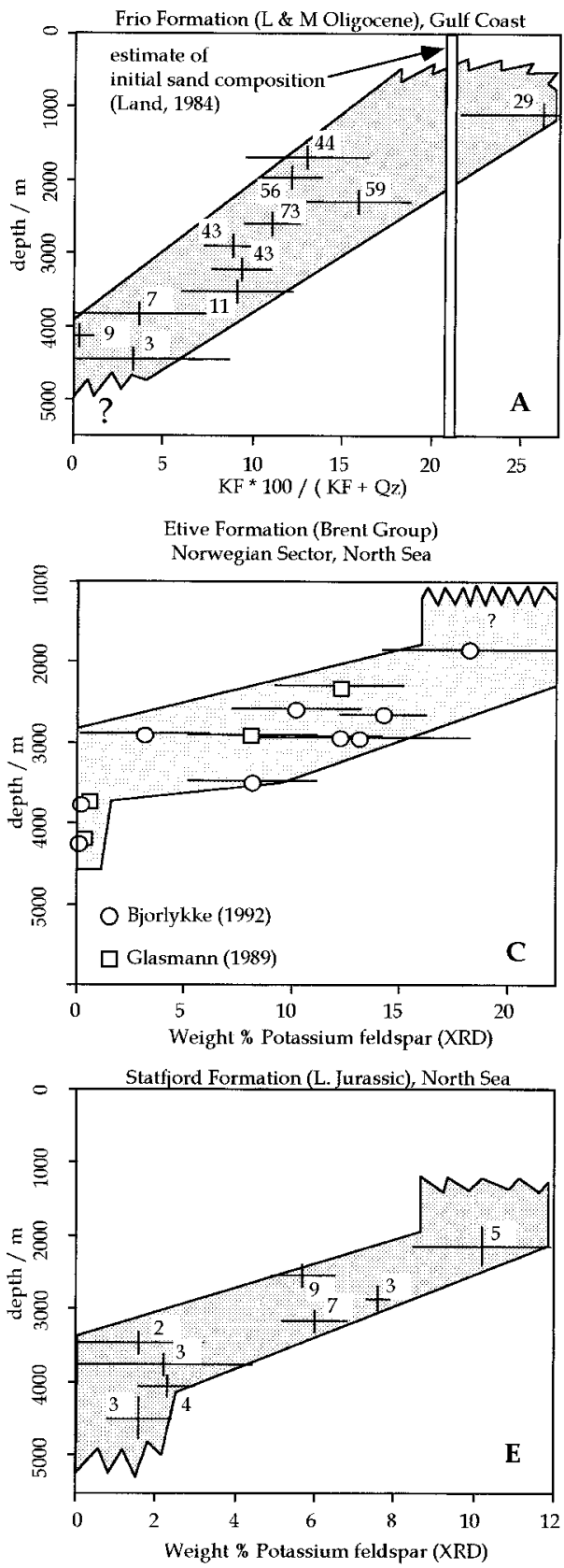

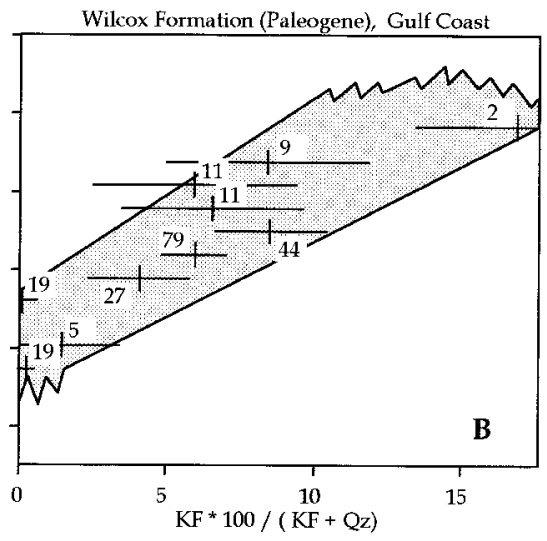

Fulmar Formation, UK North Sea (Fulmar and Clyde fields only)

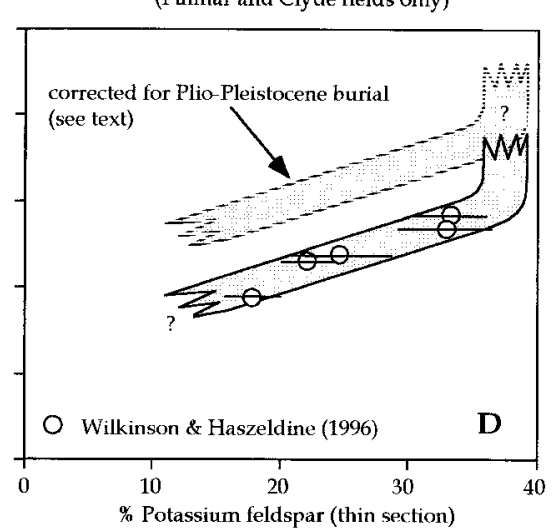

Plio-Pleistocene, Mississippi Gulf Coast

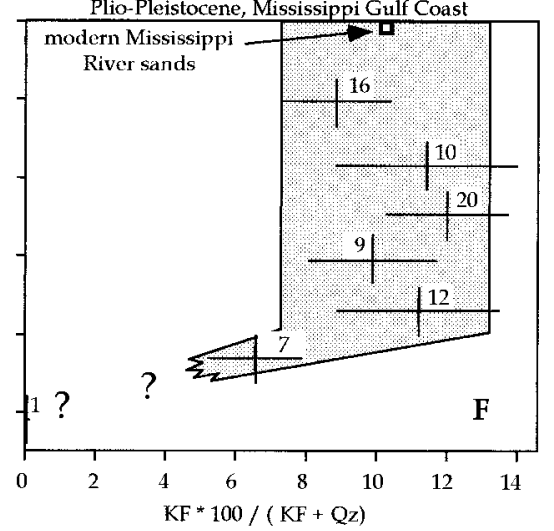

Fig. 2. (a-e) The decline in abundance of potassium feldspar with burial in a number of sedimentary basins. In none of the basins studied do significant quantities of potassium feldspar survive burial to more than $4500 \mathrm{~m}$ depth. Each of the plotted points is an average of numerous point-count analysis, the number of which is indicated on the graph. The error bars are $2 \times$ standard errors. The data from the Texas Gulf Coast are collated into $305 \mathrm{~m}$ depth intervals $(1000 \mathrm{ft})$, while the UK data are plotted for individual wells. The Gulf Coast data are presented as a ratio with detrital quartz, as the sandstones contain several types of chemically unstable grain, the abundance of which changes during burial. We assume the detrital quartz abundance to be a constant for each sandstone. For (d), the Fulmar Formation, both the interpreted abundance curve is shown (solid lines) and also the curve allowing for Plio-Pleistocene burial (dotted lines, see text). (f) The composition of Plio-Pleistocene sands from the Mississippi River Delta is the same (within two standard deviations) as modern day Mississippi River sediment to a depth of $3650-3950 \mathrm{~m}$. This shows that a decline in potassium feldspar abundance with increasing present-day depth (i.e. palaeo-distal to palaeo-proximal) is not a primary feature of a fluvio-deltaic system. The possible decline in feldspar abundance below c. $3600-3900 \mathrm{~m}$ is interpreted to represent the onset of feldspar dissolution. determining whole-rock composition. Clearly, a thin-section or a powder sample is representative of only a small volume of rock, such that analytical errors are compounded with the (less quantifiable) question of bulk-rock inhomogeneity. It is for this reason that data sets must be large (criterion 3 above) - this both reduces the influence of analytical error, and also increases the chances of obtaining representative data. The likely importance of errors (both analytical and due to rock inhomogeneity) can be assessed by the calculation of standard errors. Provided that the observed changes in sandstone composition with depth substantially exceeds the calculated errors, then a high degree of confidence can be attached to the observed trends. All results are plotted with $2 \times$ standard error bars (Fig. 2), such that uncertainties in the data sets can be assessed.

\section{Results}

For the Gulf Coast and Statfjord Formation data, alkali feldspar abundance is shown averaged in $305 \mathrm{~m}(1000 \mathrm{ft})$ or $610 \mathrm{~m}(2000 \mathrm{ft})$ depth intervals, while the remaining North Sea data are plotted by well (Fig. 2a-e). For the Frio Formation the estimated initial composition of the sandstones are shown after Land (1984). All the data from ancient sandstones shows a decrease in alkali feldspar abundance with increasing burial depth (Fig. 2a-e). The data from the Plio-Pleistocene (Fig. 2f) shows that all the sandstone has (within $2 \sigma$ uncertainty) the same composition as modern Mississippi River sand at least down to 3650-3950 m (average of 14 results from New Orleans to the Gulf of Mexico; Russell 1937). There may be a decrease in alkali feldspar abundance below this depth though there is 
insufficient data to be certain. Data from the Gulf Coast are summarized in Table 1.

\section{Discussion}

Several authors have independently suggested that alkali feldspar undergoes extensive dissolution during the burial diagenesis of sandstones (e.g. Milliken et al. 1989; Harris 1992; Wilkinson \& Haszeldine 1996). By comparing the same initial sedimentary rocks at different depths of burial, it is possible to assess the quantity of alkali feldspar which has dissolved, or been otherwise altered. In order to use this method it is necessary to make the assumption that the sediment had an initial uniform average composition. This assumption is controversial. For example, Wilkinson \& Haszeldine (1996) assumed that the Fulmar Formation (offshore UK) had an initially uniform average composition, while Oxtoby \& Gluyas (1997) argued that this could not be proven. Similarly, in each of the individual data sets, it can be argued that any change with depth is not due to dissolution or alteration, but could be the result of primary changes in sediment composition, due to, for example, provenance differences or a change in facies (Bjørlykke 1998). We examine these alternative explanations below and reject them in favour of feldspar loss due to dissolution.

\section{Depositional feldspar decline due to hydrodynamic processes?}

Could the decrease in the percentage of alkali feldspar with depth be a primary sedimentary feature? In other words, as the deeply buried sediments in a basin were generally deposited more distally within the fluvio-deltaic-marine depositional system, was there originally a decline in feldspar abundance from proximal to distal sediments? Three lines of evidence suggest that this is not the case. Firstly, Figure $2 \mathrm{f}$ shows the available data from the Plio-Pleistocene sandstones of the Mississippi Gulf Coast (Milliken 1985). Also shown is the composition of present-day sand within the Mississippi River averaged from 14 samples taken from between New Orleans and the present-day coast line (Russell 1937). Note that the Plio-Pleistocene sands have (within two standard errors) the same composition as the present-day sand down to approximately $3650-3950 \mathrm{~m}$ burial depth, i.e. they show no evidence for a proximal-distal change in sediment composition. There may be a decrease in K-feldspar abundance below this (although there is only limited data); however, this may be due to the onset of the diagenetic dissolution reaction.

It is suggested that the relatively deep onset of the K-feldspar dissolution reaction within the Mississippi River sands is due to the short (geological) time span over which the reaction has had time to occur, due to the extremely rapid burial of these sediments. Wilkinson (1991) calculated, using published rate constants, the most probable time required to dissolve a sand-sized feldspar grain as $8 \mathrm{Ma}$ at $25^{\circ} \mathrm{C}$. With a geothermal gradient of only $20^{\circ} \mathrm{C} \mathrm{km}^{-1}$ (Milliken 1988), subsurface temperatures, and therefore reaction rates, will increase only slowly with depth. Hence the low calculated dissolution rate is consistent with the late onset of the $\mathrm{K}$-feldspar dissolution reaction within the Mississippi sediments. We conclude from the above that the depositional alkali feldspar content of Mississippi-style fluvio-deltaic sandstones has been preserved by rapid burial, and does not have a
Table 1. Summary of K-feldspar contents of Gulf Coast Sandstones

\begin{tabular}{|c|c|c|c|}
\hline & $\%$ alkali Fsp & & \\
\hline Depth interval (m) & $(\%$ alkali $\mathrm{Fsp}+$ detrital $\mathrm{Qz})$ & $2 \sigma$ & $n$ \\
\hline \multicolumn{4}{|l|}{ Wilcox Formation } \\
\hline $1055-1520$ & 16.9 & 3.5 & 2 \\
\hline $1520-1830$ & 8.4 & 3.3 & 9 \\
\hline $1830-2130$ & 5.6 & 3.4 & 11 \\
\hline $2130-2440$ & 6.5 & 3.0 & 11 \\
\hline $2440-2740$ & 8.5 & 1.9 & 44 \\
\hline $2740-3050$ & 5.6 & 1.0 & 79 \\
\hline $3050-3350$ & 4.1 & 1.7 & 27 \\
\hline $3350-3655$ & 0 & 0 & 19 \\
\hline $3960-4265$ & 1.5 & 1.9 & 5 \\
\hline $4265-4570$ & 0.2 & 0.4 & 19 \\
\hline \multicolumn{4}{|l|}{ Frio Formation } \\
\hline $948-1520$ & 26.2 & 14.7 & 29 \\
\hline $1520-1830$ & 13.1 & 3.5 & 44 \\
\hline $1830-2130$ & 2.2 & 1.8 & 56 \\
\hline $2130-2435$ & 15.8 & 2.9 & 59 \\
\hline $2435-2740$ & 11.0 & 1.6 & 73 \\
\hline $2740-3045$ & 9.0 & 1.7 & 43 \\
\hline $3045-3350$ & 9.4 & 1.6 & 43 \\
\hline $3350-3655$ & 9.1 & 3.2 & 11 \\
\hline $3655-3960$ & 3.8 & 3.7 & 7 \\
\hline $3960-4265$ & 0.4 & 0.8 & 9 \\
\hline $4265-4570$ & 3.3 & 5.4 & 3 \\
\hline \multicolumn{4}{|l|}{ Plio-Pleistocene } \\
\hline $705-1525$ & 8.8 & 1.6 & 16 \\
\hline $1525-2135$ & 11.4 & 2.6 & 10 \\
\hline $2135-2745$ & 12.0 & 1.7 & 20 \\
\hline $2745-3355$ & 9.9 & 1.9 & 9 \\
\hline $3355-3965$ & 11.2 & 2.3 & 12 \\
\hline $3965-4575$ & 6.5 & 1.4 & 7 \\
\hline $4575-5355$ & 0 & - & 1 \\
\hline
\end{tabular}

strong primary proximal-distal variation. Hence we do not predict primary variations in sandstone composition with present-day burial depth in sediments from similar fluvio-deltaic environments.

Secondly, there is a negative correlation between feldspar content and grain size in sands from the northern Gulf of Mexico (Milliken et al. 1989). As, in general, sediments are more fine grained in distal settings compared to proximal ones, we might predict that feldspar would be more common in distal, more deeply buried, sediments. This is in fact the opposite of the observed trend. Thirdly, we observe the same trend of alkali feldspar decline with depth in several sedimentary basins, i.e more distal (deeper) sediments have less $\mathrm{K}$-feldspar than their more proximal (shallower) equivalents. It would require an unacceptably high degree of coincidence for this to be a primary sedimentary feature in all of the basins studied, especially since we have studied basins with a variety of sedimentary settings. The Fulmar Formation is an aggradational shallow-marine sandstone which is extensively wave reworked (Howell et al. 1996) while the Statfjord Formation includes both fluvial and shallow marine tidal deposits. The Brent Group is the deposit of a delta complex which evolved from fluvial-dominated to wave-dominated, and the Etive Formation is a foreshore-shoreface deposit of a barrier system (Cannon et al. 1992). The Texas Gulf Coast was a micro-tidal barrier island system during the deposition of the Frio and the Wilcox formations (Galloway 1986). We suggest that it is unlikely that the observed decline in alkali feldspar with depth is a primary feature in all of these different depositional 
settings, and consequently, the variation we observe in ancient sandstones is due to diagenetic effects and not to primary sedimentary patterns.

\section{Depositional feldspar decline due to provenance change?}

Could the decline in alkali feldspar with depth be the result of a change in sediment provenance during deposition? There are two scenarios to consider, either a change of source area composition during deposition, or lateral changes such that deep samples are derived from a different area to shallow samples. In the case of the Frio and Wilcox formations, we have presented data from relatively restricted geographical areas (Lower Texas and Mid Texas respectively; see Loucks et al. 1984), within which previous workers have deduced no systematic changes in detrital mineralogy (e.g. Boles 1982). This should minimize any problems with lateral or spatial changes in the provenance of the sediments. Similar alkali feldspar decrease with depth is evident in the other areas of the Texas Gulf Coast (from our own observations), even though they are supplied by different source areas (Loucks et al. 1984). Bloch et al. (1998) argued that there have been changes in the composition of sediment supplied to the Gulf Coast during the Palaeogene, though this has been strongly rebutted by Lynch et al. (1999) with whom the present authors concur.

For the Brent Group, there are several papers examining the provenance of the sedimentary rocks. Morton (1992) concluded that the Etive Formation was derived by longshore drift from the east, such that the initial feldspar content of the sediments may have decreased to the west due to the mechanical destruction of the feldspar. We have hence taken data from a relatively restricted geographical area (the Norwegian sector of the East Shetland Basin) as this should minimize the initial variation in sediment composition. Detrital garnet data of Morton (1992) shows a uniform provenance within the Norwegian sector of the East Shetland Basin. Mearns (1992), however, deduced a change in sediment provenance during the deposition of the Etive Formation based upon $\mathrm{Sm}-\mathrm{Nd}$ measurements from a single vertical sequence. However, from our own observations, there is no corresponding change in bulk mineralogy within the formation within individual wells, (remember that we are comparing changes between wells), and there is no change within detrital garnet populations except where channels of the overlying Ness Formation cut down into the Etive (A. Morton pers. comm. 2000). We do not consider that there was a significant change in sediment composition during the deposition of the Etive Formation, or that this presents a problem for our method.

It is a reasonable assumption that, in order to deposit several kilometres of sediment, then a source area will be eroded to a similar depth. Almost certainly, there will be changes in the average composition of the sediments supplied during this erosion. The question then becomes: are the changes due to the variation in the provenance area more or less important than those due to diagenesis? Since we observe patterns of decreasing K-feldspar with depth in all our rift/ passive margin basins, then either all the source areas underwent (coincidentally) similar changes in average composition during erosion, or else the changes we see are predominantly diagenetic. From the above discussion we conclude that, for the examples we have chosen, the initial composition of the bulk sandstone is sufficiently uniform such that changes with depth can be ascribed to diagenetic processes. However, it must be stressed that it is only the average initial composition of the sandstones which is uniform. Within a sandstone at any given depth there will always be a range of feldspar contents. Consequently, a 'large' (i.e. representative) sample size is a prerequisite if diagenetic trends are to be accurately ascertained. The more variable the sands, the larger the sample size required.

\section{Dissolution or alteration?}

A decrease in K-feldspar abundance within a sandstone could be due either to dissolution of the feldspar, or to in-situ alteration forming albite. The albitization process has been demonstrated to be important in both the Gulf Coast (Milliken 1989) and North Sea sediments (Saigal et al. 1988). However, studies of individual sandstones have shown that albitization is volumetrically subordinate to dissolution. For the Frio Formation, Milliken (1989) concluded that the majority of K-feldspar dissolved and only a lesser quantity was albitized. For the Fulmar Formation, Wilkinson \& Haszeldine (1996) found that the amount of albite present within the deeply buried sandstones was much smaller $(2-5 \%)$ than the quantity of feldspar dissolved (up to 30\%). Furthermore, there was no clear increase in albite abundance with depth. (Wilkinson \& Haszeldine 1996, fig. 2). For the Etive Formation, XRD data shows that the amount of albite in the sandstones stays constant or even decreases with depth (Bjørlykke et al. 1992, fig. 3d). Petrographic data from the Statfjord Formation show that albite is generally only a minor component of the sands, and increases only very slightly with depth of burial (Ramm \& Ryseth 1996, fig. 10).

Even though the abundance of alkali feldspar may progressively decrease within a sandstone with increasing burial, this does not mean that the individual alkali feldspar grains are undergoing a steady, progressive dissolution. In fact, it is a common petrographic observation that the degree of dissolution of feldspar grains within a single thin-section is highly variable. It seems likely that individual feldspar grains remain stable until a critical depth, temperature or pore fluid composition is reached at which point they undergo relatively rapid dissolution. If the resulting secondary pore is subsequently partially or totally destroyed by compaction then no evidence will remain for the previous existence of the feldspar. The quantity of secondary porosity observed petrographically today is hence not a reliable indicator of the quantity of feldspar which has undergone dissolution, but merely provides a minimum estimate (Wilkinson et al. 1997). Estimates of the quantity of missing feldspar derived by counting secondary porosity in thin-sections can be an order of magnitude less than those obtained using depth-related compositional trends (Milliken et al. 1994; Wilkinson \& Haszeldine 1996).

The observation that $\mathrm{K}$-feldspar is dissolving during deep burial $(>1.5 \mathrm{~km})$ is supported, for both the North Sea and the Gulf Coast areas, by the chemistry of the formation waters within the sandstones. Bjørlykke et al. (1995) compiled porewater data for both the above areas, and calculated that they were in equilibrium with illite, but undersaturated with respect to K-feldspar. This situation is clearly conducive to K-feldspar dissolution at depth. Bjørlykke (1998) proposed two chemical reactions whereby $\mathrm{K}$-feldspar would dissolve during deep burial to supply $\mathrm{K}$ to authigenic illite, and noted the decrease in K-feldspar over the depth interval of illite growth. It was 
also suggested that adjacent mudstones might absorb excess $\mathrm{K}$, perhaps through the illitization of smectite. In summary, modern porewater data support the continuous dissolution of $\mathrm{K}$-feldspar during deep burial diagenesis.

\section{Other methods for assessing changes in sediment composition during burial}

Calcite concretions are common features within siliciclastic sequences, and commonly form during shallow burial (e.g. Wilkinson 1991). The concretions enclose a volume of sediment and, it has been presumed, prevent diagenetic reactions after concretion growth (e.g. Gluyas \& Coleman 1992). Hence the sediment within concretions has been regarded as retaining a pre-burial composition, and it might be assumed that the initial feldspar content of a sediment can be determined by direct measurement. However, this method is not without potential problems.

The sediment-within-concretions methodology has been applied to the study of elemental fluxes between sandstones and shales: by comparing the composition of sediment inside the concretion with the time-equivalent sediment outside the concretion, then changes in sediment composition can be calculated. Gluyas \& Coleman (1992) calculated Si fluxes into sandstones from the North Sea using this method, and compared the results to the measured volume of quartz overgrowth present outside the concretions. The calculated geochemical fluxes over-estimated the measured quartz overgrowth volumes by $270-280 \%$, even disregarding the existence of intraformational sources for $\mathrm{Si}$ during diagenesis such as feldspar dissolution. Gluyas \& Coleman (1992) suggested that this mis-match was due to the difficulty of recognizing quartz overgrowth by conventional light petrography. Alternatively, one of the assumptions in the method may be at fault, particularly the idea that the calcite cement passively infills porosity and preserves the original sediment composition. Certainly, some early calcite concretions show evidence of extensive feldspar corrosion which is not evident in the surrounding, uncemented sandstone (Wilkinson 1991). The outlines of detrital feldspars which have been almost totally replaced by calcite can sometimes be imaged using cathodoluminescence techniques (e.g. in Brent Group, unpublished data), suggesting that the fluids from which concretions precipitate can be highly corrosive. Milliken et al. (1989) suggested that feldspars within calcite concretions were not protected from diagenesis, but were subjected to a different set of processes compared to feldspars within the host sandstone, for example preferential replacement by calcite. The use of calcite concretions as samples of early (pre-diagenesis) sediment may therefore be flawed.

\section{The depth and rate of alkali feldspar dissolution}

The range of burial depths and temperatures (assuming present day geothermal gradients) over which alkali feldspar dissolution has occurred, and the amount of dissolution relative to temperature increase is shown in Table 2. The difference in the depths and amount of dissolution $/{ }^{\circ} \mathrm{C}$ reflects the origin and previous history of the feldspar. In the southern Gulf Coast, the alkali feldspar is of volcanic origin, and extensive solidsolution exists between albite and orthoclase (Milliken et al. 1989). Hence much of the feldspar is unstable under surface conditions, and dissolution begins at very shallow burial
Table 2. Comparison of $K$-feldspar dissolution as a function of temperature

\begin{tabular}{lcrc}
\hline Formation & $\begin{array}{c}\text { Depth } \\
\text { interval }(\mathrm{m})\end{array}$ & $\begin{array}{c}\text { Temperature } \\
\text { range }\left({ }^{\circ} \mathrm{C}\right)\end{array}$ & $\begin{array}{c}\text { K-feldspar dissolution } \\
\text { as \% solid volume } /{ }^{\circ} \mathrm{C}\end{array}$ \\
\hline Wilcox & $1500-5000$ & $73-163$ & 0.06 \\
Statfjord & $2000-4000$ & $87-150$ & 0.1 \\
Brent & $1800-3800$ & $75-140$ & 0.3 \\
Fulmar & $3200-4200$ & $125-158$ & 0.5 \\
Frio & $1200-4750$ & $57-154$ & 0.05 \\
\hline
\end{tabular}

Present-day geothermal gradients are assumed.

depths. Even in our most shallowly buried samples (1200$1500 \mathrm{~m}$ ) secondary porosity after feldspar averages $19 \pm 6 \%$ in the Frio Formation and $16 \pm 10 \%$ in the Wilcox Formation. Subsequent dissolution of the geochemically more stable remaining feldspar is much less rapid. In the Brent Group (and probably the Statfjord Formation), the sand was derived from amphibolite-facies metamorphic basement rocks of southern Norway (Morton 1992). The high temperature (close to endmember) feldspars derived from this source are fairly stable during weathering and burial, so that there is little dissolution before c. $2000 \mathrm{~m}$. Secondary porosity after feldspar at this depth is 2-4.5\% (Bjørlykke et al. 1992). The Fulmar Formation was derived from texturally mature Permo-Triassic continental strata (Johnson et al. 1986) such that the feldspars are at least second cycle, and had been subjected to burial diagenetic dissolution at least once prior to incorporation in to the Fulmar Formation. The existence of sands with an average of $30 \%$ feldspar at $3000 \mathrm{~m}$ burial depth (which is similar to the composition of the Triassic source rocks) suggests that there was little dissolution above this depth. Dissolution below this depth was rapid, with the removal of c. $15 \%$ feldspar over a $33^{\circ} \mathrm{C}$ temperature interval.

In contrast, the Plio-Pleistocene and Recent sands show no discernible K-feldspar dissolution until buried to at least $3650 \mathrm{~m}$, i.e. burial to around $100^{\circ} \mathrm{C}$ over $2-5 \mathrm{Ma}$ has not resulted in significant reaction. This is partly controlled by the mineralogy of the K-feldspars (predominantly microcline), but otherwise suggests that the $\mathrm{K}$-feldspar dissolution reaction is geologically slow, as discussed above. This has clear implications for the interpretation of data from other rapidly buried sequences-for example the Fulmar Formation, which has undergone almost $1 \mathrm{~km}$ of burial during the Plio-Pleistocene (Darby et al. 1997). It is possible that the feldspar dissolution trend in the Fulmar is 'fossil', i.e. does not represent current $P-T$ conditions, but represents those conditions pertaining before the Plio-Pleistocene burial. If this is the case, then the true depth of K-feldspar dissolution within the Fulmar Formation is not $3-4.5 \mathrm{~km}$, but $2-3.5 \mathrm{~km}$ (Fig. 2d). This implies that $\mathrm{K}$-feldspar is undergoing dissolution at the present day in Fulmar Formation sandstones buried to less than $4.5 \mathrm{~km}$.

\section{Geochemical implications and wider significance}

This is the first time that a pattern of progressive feldspar decline with depth has been demonstrated for a range of depositional environments from different basin settings. This is systematic and similar in five sandstone successions from three basins within rift and passive margin settings. The existence of such dissolution has been controversial, but must now be recognized as an important process. This process has 
implications for the size of geochemical system closure in the deep subsurface, and for processes of compaction. The fate of dissolution products remains unknown, as mass-balance suggests that insufficient growth of Al-bearing cements has occurred as a 'sink' in many formations (e.g. Wilkinson \& Haszeldine 1996; Land \& Macpherson 1992; Milliken et al. 1994). A simple explanation is that the deep sandstone is not always a closed geochemical system, but interacts with its enclosing mudrocks (see Boles \& Franks 1979; Gluyas \& Coleman 1992; Land et al. 1997; Macaulay et al. 1998).

Petrographic textures diagnostic of pristine secondary porosity after feldspar are not common in deep sandstones, usually forming less than $3-5 \%$ of the whole rock (e.g. Bjørlykke et al. 1992). However, if wider petrographic criteria are used for the definition of secondary porosity, then the ratio of secondary:primary porosity systematically increases in the deep Etive Formation (Giles et al. 1992). Similar effects of increasing secondary porosity ratio are seen in plagioclase feldspar sandstones from the San Joaquin Basin (Bloch 1994). We interpret this as indicating that secondary porosity in a sandstone is continually formed, but also continually destroyed by compaction or cementation during deep burial. This process has not been widely recognized. Many petrographic studies are in fact only recognizing the secondary porosity that has been most recently formed at depth. Clearly the volume of secondary porosity which is preserved depends upon the fluid overpressure within the sand (Wilkinson et al. 1997).

We suggest that secondary porosity is not a reliable indicator of the quantity of alkali feldspar which has undergone dissolution in a deeply buried sandstone, consequently any reconstruction of the original composition of the sandstone, based upon an estimate of secondary porosity abundance, is bound to be in error. This has important implications for studies of sedimentary provenance and also geochemistry. It is also important to fully understand the dissolution history of alkali feldspar if the porosity evolution of sandstones during intermediate and deep burial is to be correctly understood and predicted.

\section{Sandstones with deep K-feldspar preservation}

In some sandstones K-feldspar does not undergo dissolution over the depth range $1.5-4.5 \mathrm{~km}$. Published examples include the turbiditic Stevens Sandstone of the San Joaquin Basin of California, USA (Boles 1987); the volcaniclastic sandstones of the Murihiku Supergroup of New Zealand (Boles \& Coombs 1977) and the Norphlet Sandstone of the USA Gulf Coast (McBride et al. 1987). In all three examples, $\mathrm{K}$-feldspar is present as a late-stage authigenic cement. This contrasts with the sandstones showing K-feldspar dissolution, where Kfeldspar cement is only formed during very early burial, and albite is the stable feldspar at depth. As sea-water is oversaturated with respect to K-feldspar (Bjørlykke et al. 1995), it is reasonable to presume that such early $\mathrm{K}$-feldspar cements form in fluids of close to seawater composition. For sandstones hosting K-feldspar cements and preserved detrital K-feldspar, then thermodynamic calculations give a guide to the conditions which must have prevailed during burial. From the activity diagram of Aagaard \& Helgeson (1983, fig. 10), it is apparent that $\mathrm{K}$-feldspar is stabilized by high $\mathrm{K}+/ \mathrm{H}+$ ratios and high silica activities. There are a number of geological scenarios that may lead to such conditions, and hence to K-feldspar preservation during burial.
Many rift basins contain evaporite minerals deposited during the early stages of rifting (e.g. Central North Sea). If these are K-rich, and brines derived by dissolution can enter adjacent sandstones, then they will stabilize K-feldspar. Both the composition of these deposits (especially the $\mathrm{Ca}+\mathrm{Na}: \mathrm{K}$ ratio) and their degree of fluid connectivity with the sandstones must be important in determining the extent of K-feldspar preservation. The Upper Jurassic Norphlet Sandstone of the Mississippi and Alabama Gulf Coast illustrates this (McBride et al. 1987). The Norphlet Sandstone lies upon an evaporite sequence, the Louann Salt, which is capped by an intergrown sylvite-halite deposit which formed by the evaporation of bittern brines. There is no recorded K-feldspar dissolution, instead plagioclase dissolution is observed petrographically. The sand preserves an arkosic composition during deep burial $(10 \pm 1 \% \mathrm{~K}$-feldspar at $4500-6000 \mathrm{~m}$ burial depth, McBride et al. 1987, table 2) due to high $\mathrm{K}$ concentrations in porewaters influenced by the underlying evaporites (McBride et al. 1987).

In the absence of an external $\mathrm{K}$ source, then the breakdown of volcanic clasts can also lead to increased $\mathrm{K}+$ concentrations within porewaters (Surdam et al. 1989). Otherwise, high $\mathrm{pH}$ will stabilize K-feldspar, and will also promote the growth of zeolite cements, such as laumontite (Crossey et al. 1984), and $\mathrm{K}$-feldspar overgrowths. Zeolites are associated with preserved K-feldspar in the Murihiku Supergroup of New Zealand (Boles \& Coombs 1977). As laumontite stability is favoured by both high $\mathrm{pH}$ and low $P_{\mathrm{CO}}$, and these conditions are unlikely in a basin containing maturing organic matter, then K-feldspar preservation and the precipitation of laumontite are favoured in basins which do not contain deeply buried organic-rich deposits.

A high activity of $\mathrm{SiO} 2$ (which favours K-feldspar preservation, Aagaard \& Helgeson 1983) can be produced by the breakdown of unstable volcanic clasts within a sandstone (Surdam et al. 1989), presuming that these clasts survive into deep burial. As an example, the Murihiku Supergroup which contains abundant volcanic detritus has both authigenic zeolites and K-feldspar preservation. Within the data available to us, we have observed a general association between K-feldspar preservation and a suite of diagenetic changes including formation of zeolites, K-feldspar overgrowths and the dissolution or albitization of plagioclase.

The stability of detrital K-feldspar may, alternatively, be controlled by the clay mineral assemblage within the basin. In rift and passive margin basins the dominant clay minerals are smectite and illite-smectite. Hence the volumetrically dominant diagenetic reaction is likely to be the transformation of smectite to illite. While the mass-balance of this reaction has been heavily debated, recent work favours an import of $\mathrm{K}$ into the deeply buried shales (>2 km; Awwiller 1993; Wintsch \& Kvale 1994; Land et al. 1997; Berger et al. 1997). Noting that $\mathrm{K}$-feldspar dissolution takes place over a similar depth interval as the smectite to illite transformation, Wilkinson et al. (2001) suggested that $\mathrm{K}$ (and Al?) from the dissolution of $\mathrm{K}$-feldspar within sandstones was transported into adjacent shales to be incorporated into smectite altering to illite. They further suggested the rate of the two reactions could be coupled, such that the rate of the K-feldspar dissolution-transportillitization system would be controlled by the slowest of the three steps. Here, we further suggest that the stability of $\mathrm{K}$-feldspar within sandstones may be controlled by the presence or absence of illitizing smectite within mudrocks. If smectite and illite-smectite are present as a sink for $\mathrm{K}$ (and Al?) then K-feldspar within the sandstones undergoes 


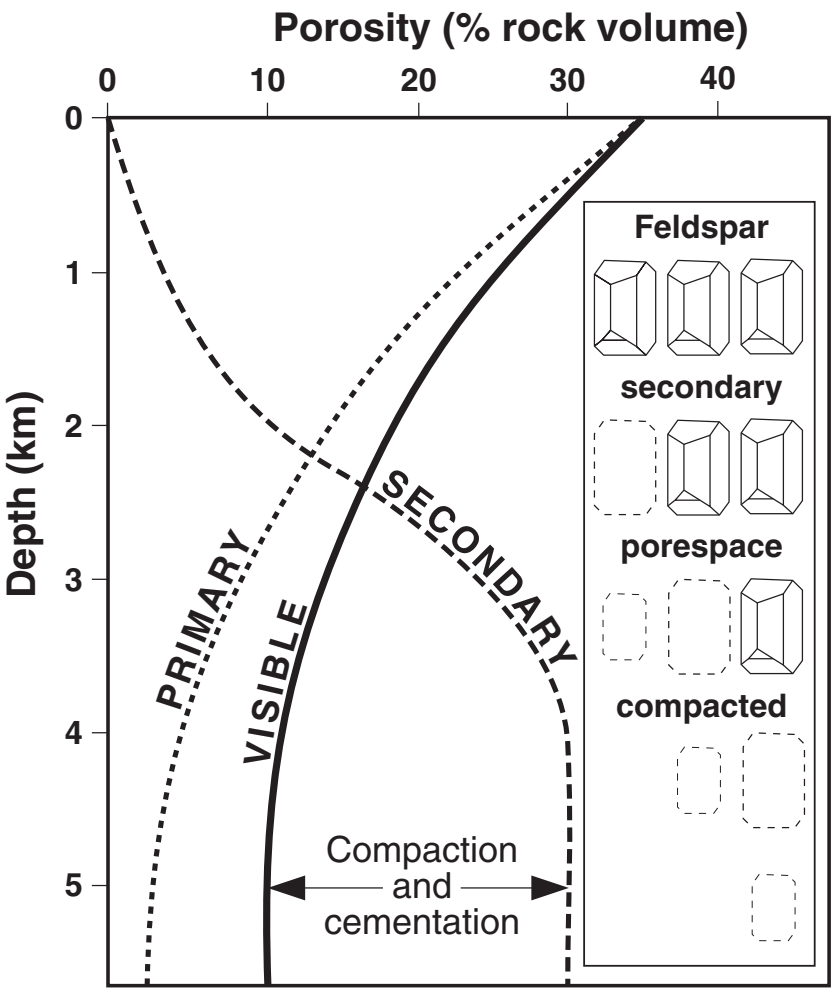

Fig. 3. Cartoon showing feldspar decline with depth, indicating that primary inter-grain porosity decreases with depth due to compaction. Secondary porosity is interpreted to increase with depth, due to progressive dissolution of feldspar. The total porosity generated is never visible at any one time because of the continuing compaction of both primary and secondary porosity. The proportion of secondary porosity increases with depth. Textures diagnostic of secondary porosity are not preserved, so that petrographic and thin-section point-count techniques lead to an underestimate of the importance of the secondary porosity type.

dissolution, otherwise K-feldspar remains stable during deep burial. In basins with a high volcanic input, then clay mineral assemblages will be dominated by chlorite, hence K-feldspar will be stable during burial within volcanic arc settings.

\section{Conclusions}

(1) A common pattern of K-feldspar decline during deep burial has been demonstrated in different basins from rift/passive margin settings. Examples are from the USA Gulf Coast passive margin basin, and two different rift basins of the North Sea, where five sandstone formations were deposited in different sedimentary environments with initial K-feldspar contents of up to $30 \%$ volume.

(2) Arkosic sandstones show a systematic and progressive decrease of $\mathrm{K}$-feldspar to average less than $5 \%$ volume. This occurs during burial from 1.5 to $4.5 \mathrm{~km}$ (Fig. 3). This demonstrates that feldspar dissolution is an important process in the deep subsurface, and is not restricted to shallow depths with high fluxes of meteoric water.

(3) K-feldspar decline with progressive burial is not a primary depositional or provenance variation, as this would need to coincide in all five formations studied. This is further demonstrated by Modern and Plio-Pleistocene sediments from the Mississippi which show uniform K-feldspar content until burial exceeds $4.0 \mathrm{~km}$ after which K-feldspar decreases.
(4) Petrographic criteria diagnostic of secondary porosity are destroyed by progressive compaction (Fig. 3), so that the extent of $\mathrm{K}$-feldspar dissolution is under-estimated by conventional interpretation of point-count data. Hence, deeply buried or exhumed sandstones are not a reliable record of depositional composition. Arkoses at shallow depth will become sub-arkoses or quartzites at greater depth.

(5) Sandstones from other sedimentary settings (volcanic arc, strike-slip basin) may preserve $\mathrm{K}$-feldspar to depths in excess of $5 \mathrm{~km}$. This is associated with either high $\mathrm{K}^{+} / \mathrm{H}^{+}$ ratios, high $\mathrm{SiO}_{2}$ activities, or a clay mineral assemblage lacking in illite-smectite within the surrounding mudrocks.

M.W. was funded by RoPA grant no. GR3/R9671 from the Natural Environmental Research Council (UK). Thanks to Earle McBride for allowing us to use his data. Reviews by Jim Boles and Jon Gluyas substantially improved the paper. Two additional referees chose to remain anonymous. Thanks to Duncan Pirrie for his editorial assistance.

\section{References}

Aagaard, P. \& Helgeson, H.C. 1983. Activity composition relations among silicates and aqueous-solutions. 2. chemical and thermodynamic consequences of ideal mixing of atoms on homological sites in montmorillonites, illites, and mixed-layer clays. Clays and Clay Minerals, 31, 207-217.

Awwiller, D.N. 1993. Illite/smectite formation and potassium mass transfer during burial diagenesis of mudrocks: A study from the Texas Gulf Coast Paleocene-Eocene. Journal of Sedimentary Petrology, 63, 501-512.

Berger, G., Lacharpagne, J.C., Velde, B., Beaufort, D. \& Lanson, B. 1997. Kinetic constraints on illitization reactions and the effects of organic diagenesis in sandstone/shale sequences. Applied Geochemistry, 12, 23-35.

BJøRLYKKe, K. 1984. Formation of secondary porosity: how important is it? In: McDonald, D.A. \& Surdam, R.C. (eds) Clastic Diagenesis. American Association of Petroleum Geologists. Memoirs, 37, 277-286.

BJøRLYKKe, K. 1998. Clay mineral diagenesis in sedimentary basins - a key to the prediction of rock properties. Examples from the North Sea Basin. Clay Minerals, 33, 15-34.

Bjørlykke, K., Nedkvitne, T., Ramm, M. \& Saigal, G.C. 1992. Diagenetic processes in the Brent Group (Middle Jurassic) reservoirs, of the North Sea: an overview. In: Morton, A.C., Haszeldine, R.S., Giles, M.R. \& Brown, S. (eds) Geology of the Brent Group. Geological Society, London. Special Publications, 61, 263-287.

Bjørlykke, K., Aagaard, P., Egeberg, P.K. \& Simmons, S.P. 1995. Geochemical constraints from formation water analyses from the North Sea and the Gulf Coast basins on quartz, feldspar and illite precipitation in reservoir rocks. In: CubitT, J.M. \& England, W.A. (eds) The Geochemistry of Reservoirs. Geological Society, London. Special Publications, 86, 33-50.

Bloch, J., Hutcheon, I.E. \& De Caritat, P. 1998. Tertiary volcanic rocks and the potassium content of Gulf Coast shales - the smoking gun. Geology, 26, 527-530.

BLOCH, S. 1994. Effects of detrital mineral composition on reservoir quality. In: Wilson, M.D. (ed.) Reservoir Quality Assessment and Prediction in clastic Rocks. SEPM (Society for Sedimentary Geology). Short Courses, 30, $161-182$.

Boles, J.R. 1982. Active albitisation of plagioclase, Gulf Coast Tertiary. American Journal of Science, 282, 165-180.

Boles, J. R. 1987. Six million year diagenetic history, North Coles Levee, San Joaquin Basin, California. In: Marshall, J.D. (ed.) Diagenesis of Sedimentary Sequences. Geological Society, London. Special Publications, 36, 191-200.

Boles, J.R. \& Coombs, D. S. 1977. Zeolite facies alteration of sandstones in the Southland Syncline, New Zealand. American Journal of Science, 277, 982-1012.

Boles, J.R. \& Franks, S.G. 1979. Clay diagenesis of Wilcox sandstones of southwest Texas: implications of smectite diagenesis on sandstone cementation. Journal of Sedimentary Petrology, 49, 55-70.

Cannon, S.J.C., Giles, M.R., Whitaker, M.F., Please, P.M. \& Martin, S.V. 1992. A regional reassessment of the Brent Group, UK sector, North Sea. In: Morton, A.C., Haszeldine, R.S., Giles, M.R. \& Brown, S. (eds) Geology of the Brent Group. Geological Society, London. Special Publications, 61, 81-107. 
Crossey, L.J., Frost, B.R. \& Surdam, R.C. 1984. Secondary porosity in laumontite-bearing sandstones. In: MCDonald, D.A. \& SuRdam, R.C. (eds) Clastic Diagenesis. American Association of Petroleum Geologists. Memoirs, 37, 225-237.

Darby, D., Wilkinson, M., Fallick, A.E. \& Haszeldine, R.S. 1997. Illite dates record deep fluid movements in petroleum basins. Petroleum Geology, 3, 133-140.

Dickinson, W. R. \& SuczeK, C.A. 1979. Plate tectonics and sandstone compositions. American Association of Petroleum Geologists Bulletin, 63, 2164 2182.

FISHER, R.S. 1982. Diagenetic history of Eocene Wilcox sandstones and associated formation waters, south-central Texas. $\mathrm{PhD}$ dissertation. University of Texas at Austin.

GallowAY, W.E. 1986. Reservoir facies architecture of microtidal barrier systems. American Association of Petroleum Geologists Bulletin, 70, 787808 .

Glasmann, J.R., Clark, R.A., Larter, S., Briedis, N.A. \& Lundegard, P.D. 1989. Diagenesis and hydrocarbon accumulation, Brent Sandstone (Jurassic), Bergen High area, North Sea. American Association of Petroleum Geologists Bulletin, 73, 1341-1360.

GiLes, M.R. \& De Boer, R.B. 1990. Origin and significance of redistributional secondary porosity. Marine and Petroleum Geology, 7, 378-397.

Giles, M.R., Stevenson, S., Martin, S.V., Cannon, S.J.C., Hamilton, P.J., Marshall, J.D. \& Samways, G.M. 1992. The reservoir properties and diagenesis of the Brent Group: a regional perspective. In: MorTon, A.C., Haszeldine, R.S., Giles, M.R. \& Brown, S. (eds) Geology of the Brent Group. Geological Society, London. Special Publications, 61, 289-327.

Gluyas, J. \& Coleman, M. 1992. Material flux and porosity changes during sediment diagenesis. Nature, 356, 52-54.

HARRIS, N.B. 1992. Burial diagenesis of Brent Sandstones: a study of Statfjord, Hutton and Lyell fields. In: Morton, A.C., Haszeldine, R.S., Giles, M.R. \& Brown, S. (eds) Geology of the Brent Group. Geological Society, London. Special Publications, 61, 351-376.

Howell, J.A., Flint, S.S. \& Hunt, C. 1996. Sedimentological aspects of the Humber Group (Upper Jurassic) of the South Central Graben, UK North Sea. Sedimentology, 43, 89-114.

Johnson, H.D., Mackay, T.A. \& Stewart, D.J. 1986. The Fulmar oil-field (Central North Sea): geological aspects of its discovery, appraisal and development. Marine and Petroleum Geology, 3, 99-125.

LAND, L.S. 1984. Frio Sandstone Diagenesis, Texas Gulf Coast: a regional isotopic study. In: MCDonald, D.A. \& Surdam, R.C. (eds) Clastic Diagenesis. American Association of Petroleum Geologists. Memoirs, 37, 47-62.

Land, L.S., MaCK, L.E., Milliken, K.L. \& LynCH, F.L. 1997. Burial diagenesis of argillaceous sediment, south Texas Gulf of Mexico sedimentary basin: a reexamination. Geological Society of America Bulletin, 109, 2-15.

LAND, L.S. \& MACPHERSON, G.L. 1992. Origin of saline formation waters, Cenozoic section, Gulf-of-Mexico sedimentary basin. American Association of Petroleum Geologists Bulletin, 76, 1344-1362.

Loucks, R.G., DodGe, M.M. \& Galloway, W.E. 1984. Regional controls on diagenesis and reservoir quality in Lower Tertiary sandstones along the Texas Gulf Coast. In: McDonald, D.A. \& Surdam, R.C. (eds) Clastic Diagenesis. American Association of Petroleum Geologists. Memoirs, 37, $15-46$.

Lynch, F.L., Milliken, K.L., Awwiller, D.N. \& Mack, L.E. 1999. Tertiary volcanic rocks and the potassium content of Gulf Coast shales - the smoking gun: Comment and Reply. Geology, 27, 663.

Macaulay, C. I., Fallick, A. E., Mclaughlin, O. M., Haszeldine, R. S. \& Pearson, M. J. 1998. The significance of $\delta 13 \mathrm{C}$ of carbonate cements in reservoir sandstones: a regional perspective from the Jurassic of the northern North Sea. In: MoRAD, S. (ed.) Carbonate Cementation of Sandstones. International Association of Sedimentologists. Special Publications, 26, 395-408.

McBride, E. F., LAND, L. S. \& MACK, L. E. 1987. Diagenesis of eolian and fluvial feldspathic sandstones, Norphlet Formation (Upper Jurassic), Rankin County, Mississippi, and Mobile County, Alabama. American Association of Petroleum Geologists Bulletin, 71, 1019-1034.
McLaughlin, O.M., Haszeldine, R.S., Fallick, A.E. \& Rogers, G. 1994. The case of the missing clay, aluminium loss and secondary porosity, South Brae Oilfield, North Sea. Clay Minerals, 29, 651-664.

Mearns, E. W. 1992. Samarium-neodynium isotopic constraints on the provenance of the Brent Group. In: Morton, A.C., Haszeldine, R.S., Giles, M.R. \& Brown, S. (eds) Geology of the Brent Group. Geological Society, London. Special Publications, 61, 213-225.

Milliken, K.L. 1985. Petrology and burial diagenesis of Plio-Pleistocene sediments, Northern Gulf of Mexico. PhD thesis. University of Texas at Austin.

Milliken, K.L. 1988. Loss of provenance information through subsurface diagenesis in Plio-Pleistocene sandstones, Gulf of Mexico. Journal of Sedimentary Petrology, 58, 992-1002.

Milliken, K.L. 1989. Petrography and composition of authigenic feldspars, Oligocene Frio formation, South Texas. Journal of Sedimentary Petrology, 59, 361-374.

Milliken, K.L. 1992. Chemical behavior of detrital feldspars in mudrocks versus sandstones, Frio Formation (Oligocene), South Texas. Journal of Sedimentary Petrology, 62, 790-801.

Milliken, K.L., MCBride, E.F. \& LAND, L.S. 1989. Numerical assessment of dissolution versus replacement in the subsurface destruction of detrital feldspars, Frio Formation, South Texas. Journal of Sedimentary Petrology, 59, 740-757.

Milliken, K.L., MacK, L.E. \& Land, L.S. 1994. Elemental mobility in sandstones during burial: whole-rock chemical and isotopic data, Frio formation, south Texas. Journal of Sedimentary Research, A64, 788-796.

Morton, A.C. 1992. Provenance of Brent Group sandstones: heavy mineral constraints. In: Morton, A.C., Haszeldine, R.S., Giles, M.R. \& Brown, S. (eds) Geology of the Brent Group. Geological Society, London. Special Publications, 61, 227-244.

Oxтовy, N. \& Gluyas, J. 1997. Discussion on aluminum loss during sandstone diagenesis. Journal of the Geological Society, London, 154, 747-751.

Ramm, M. \& RYSETH, A.E. 1996. Reservoir quality and burial diagenesis in the Statfjord Formation, North Sea. Petroleum Geoscience, 2, 313-324.

Russell, R.D. 1937. Mineral composition of Mississippi River sands. Geological Society of America Bulletin, 48, 1307-1348.

Saigal, G.C., Morad, S., Bjørlykke, K., Egeberg, P.K. \& Aagaard, P. 1988. Diagenetic albitisation of detrital K-feldspar in Jurassic, Lower Cretaceous and Tertiary clastic reservoir rocks from offshore Norway, I. Texture and origin. Journal of Sedimentary Petrology, 58, 1003-1013.

SChmidT, V. \& McDonald, D.A. 1977. The role of secondary porosity in the course of sandstone diagenesis. In: Scholle, P.A. \& Schluger, P.R. (eds) Aspects of Diagenesis. Society of Economic Paleontologists and Mineralogists. Special Publications, 26, 209-226.

Surdam, R.C., MacGowan, D.B. \& Dunn, T.L. 1989. Diagenetic pathways of sandstone and shale sequences. Contributions to Geology, University of Wyoming, 27, 21-31.

WiLKINSON, M. 1991. The concretions of the Beareraig Sandstone Formation: geometry and geochemistry. Sedimentology, 38, 899-912.

Wilkinson, M. \& HasZeldine, R.S. 1996. Aluminium loss from arkoses produces diagenetic quartzites and secondary porosity: Fulmar Formation, North Sea. Journal of the Geological Society, London, 153, 657-660.

WiLKINSON, M. \& HASZELDINE, R.S. 1997. Discussion on aluminium loss during sandstone diagenesis. Journal of the Geological Society, London, 154, $747-751$.

Wilkinson, M., Darby, D., Haszeldine, R.S. \& Couples, G. D. 1997. Secondary porosity generation during deep burial associated with overpressure leak-off: Fulmar Formation UKCS. American Association of Petroleum Geologists Bulletin, 81, 803-813.

Wilkinson, M., Haszeldine, R.S. \& Milliken, K.L. 2001. Cross formational flux of aluminium and potassium in Gulf Coast sediments. In: WORDEN, R. \& Morad, S. (eds) Clay Cements within Sandstones. International Association of Sedimentologists. Special Publications, in press.

WinTSCH, R.P. \& KVALE, C.M. 1994. Differential mobility of elements in burial diagenesis of siliciclastic rocks. Journal of Sedimentary Research, $\mathbf{6 4}$ 349-361. 